\title{
KEBERADAAN USAHATANI SAPI PERAH PENGHASIL BAHAN BAKU INDUSTRI PENGOLAHAN SUSU DI DAERAH ISTIMEWA YOGYAKARTA
}

\author{
Sudi Nurtini', S. Widodo ${ }^{2}$, K. A. Santosa ${ }^{1}$ dan Masyhuri $^{2}$
}

\begin{abstract}
INTISARI
Penelitian ini bertujuan untuk mengetahui keberadaan usahatani sapi perah penghasil bahan baku Industri Pengolahan Susu (IPS) terutama yang berkaitan dengan tingkat keuntungan finansial dan keuntungan sosial yang diperoleh, serta keunggulan kompetitif dan komparatif.. Penelitian dilakukan di Kecamatan Cangkringan, Pakem, Tempel, dan Turi, Kabupaten Sleman DIY. Responden adalah 160 peternak sapi perah yang dipilih secara stratified sampling dan terbagi atas empat strata. Pemilikan satu sampai tiga Unit Ternak (UT) dengan proporsi sapi laktasi $<70 \%$ (strata 1), Pemilikan satu sampai tiga UT dengan proporsi sapi laktasi $70 \%$ (strata 2), Pemilikan $>3$ UT dengan proporsi sapi laktasi $<70 \%$ (strata 3), dan Pemilikan $>3$ UT dengan proporsi sapi laktasi $\geq 70 \%$ (strata 4). Data dianalisis dengan menggunakan PAM (Policy Analysis Matrix). Hasil penelitian menunjukkan bahwa hanya strata 4 yang mempunyai nilai keuntungan finansial positif dan mempunyai keunggulan kompetitif, sedangkan untuk keuntungan sosial yang positif adalah strata 2 dan 4 serta rata-rata DIY yang sekaligus mempunyai keunggulan komparatif. Disimpulkan bahwa usahatani sapi perah di DIY yang mempunyai keuntungan finansial dan sosial serta mempunyai keunggulan kompetitif maupun komparatif adalah strata 4. Analisis sensitivitas menunjukkan bahwa usahatani sapi perah di DIY akan mencapai keuntungan finansial yang positif dan memiliki keunggulan kompetitif apabila harga susu segar di tingkat koperasi naik $>22,41 \%$ atau Rp $1.909,57$ per liter atau tarif impor bahan baku susu naik $>34 \%$, serta akan bertahan memiliki keuntungan sosial yang positif dan keunggulan komparatif apabila nilai tukar rupiah menguat di bawah $11,05 \%$ ( $>$ Rp $8.555,62$ per US\$) atau harga bahan baku susu impor turun di bawah $11.04 \%$ ( $>$ Rp $1.459,80$ per liter).
\end{abstract}

(Kata kunci : Usahatani sapi perah, Keuntungan finansial, Keuntungan sosial, Keunggulan Kompetitif, Keunggulan komparatif).

Buletin Peternakan $29(2): 79$ - 87, 2005

'Fakultas Peternakan Universitas Gadjah Mada Yogyakarta.

${ }^{2}$ Fakultas Pertanian Universitas Gadjah Mada Yogyakarta. 


\title{
THE EXISTENCE OF DAIRY FARMING AS THE RAW MATERIAL SUPPLIER TO MILK PROCESSING INDUSTRY IN YOGYAKARTA SPECIAL REGION
}

\begin{abstract}
The objective of this research were to evaluate the existence of dairy farming as the raw material supplier to milk processing industry especially in relation to financial profits, social profits, competitive advantage and comparative advantage. The research was conducted at Cangkringan, Pakem, Tempel and Turi in Sleman, Yogyakarta Special Region. One hundred and sixty respondents were collected by stratified sampling, divided into four strata. One to three AU ownership with $>70 \%$, lactation cow (stratum 1), one to three AU ownership with $70 \%$ lactation cow (stratum 2), more than three AU ownership with $<70 \%$ lactation cow (stratum 3), and more than three AU ownership with $70 \%$ lactation cow (stratum 4 ). The data were analyzed by Policy Analysis Matrix (PAM). The results of this research showed that only stratum 4 had positive financial profit and competitive advantage, while strata 2, 4 and DIY (total average) had positive social profit and comparative advantage. It was concluded that only stratum 4 had positive financial profit, positive social profit, competitive advantage and comparative advantage. Sensitivity analysis resulted in DIY would achieve positive financial profit and competitive advantage if domestic fresh milk price rises of above $22,41 \%$ ( $>$ Rp $1.909,57$ per liter), or tariff of above $34 \%$ imposes, and keep obtaining positive social profit and comparative advantage if shadow exchange rate rises of below $11,05 \%$ ( $>\operatorname{Rp} 8.555,62$ per US\$) or imported milk price decrease of below $11,04 \%$ (>Rp $1.459,80$ per liter).
\end{abstract}

(Key words: Dairy cattle farming, Financial profit, Social profit, Competitive advantage, Comparative advantage).

\section{Pendahuluan}

Daerah Istimewa Yogyakarta (DIY), sebagai salah satu daerah pengembangan sapi perah di Indonesia, mempunyai populasi dan produksi susu yang selalu meningkat dari tahun ke tahun serta mempunyai akses pasar yang cukup strategis karena di daerah ini terdapat satu Industri Pengolahan Susu (IPS) dari sejumlah IPS yang ada di Indonesia, Sebagai salah satu daerah pengembangan sapi perah, DIY memang belum sebesar daerah-daerah pengembangan lainnya di Jawa, namun justru keadaan itu merupakan tantangan bagi pembuat kebijakan maupun masyarakat peternakan untuk menggali potensi yang ada agar predikat DIY sebagai daerah pengembangan sapi perah dapat terwujud.

Usaha sapi perah di Indonesia sebenarnya memiliki keunggulan komparatif dari segi penggunaan sumberdaya domestik. Dengan demikian susu domestik memiliki potensi untuk bersaing dengan susu impor. Daya saing suatu komoditas sering diukur dengan menggunakan pendekatan keunggulan komparatif dan kompetitif. Keunggulan komparatif merupakan suatu konsep yang dikembangkan oleh David Ricardo untuk menjelaskan efisiensi alokasi sumberdaya di suatu negara dalam sistem ekonomi yang terbuka (Warr, 1992). Menurut Januar (2002), dalam menghadapi masa depan, terjadi beberapa perubahan dan perkembangan fundamental yang terjadi perlu diantisipasi oleh masing-masing wilayah. Di satu pihak sebagai ciri dari globalisasi, yaitu tradisi efisien, produktif dan lestari (sustainable) untuk menuju pada daya saing (competitiveness), sementara di pihak lainnya haruslah pula mempertimbangkan aspek-aspek potensial (resource endowment) yang dimilikinya maupun pemberdayaan masyarakat, serta pengembangan wilayahnya. Kita hendaknya sepakat bahwa 
penyediaan pangan, termasuk di dalamnya susu segar, di tingkat daerah/wilayah tidak terlepas dari kebijakan di tingkat nasional yang berpijak pada terjaminnya ketahanan pangan nasional dengan memperhatikan daya saing untuk meningkatkan efisiensi. Adanya Instruksi Presiden No. 4 Tahun 1998, maka bentuk proteksi dalam perdagangan susu yang berlaku saat ini adalah tarif impor sebesar 5\%. Proteksi dengan tarif atau bea masuk antara lain bertujuan untuk melindungi industri dalam negeri (Pindyck dan Rubinfeld, 1998). Tarif yang dikenakan dalam suatu komoditas impor akan mengakibatkan harga komoditas tersebut di pasar domestik menjadi lebih mahal/tinggi sehingga produk domestik dapat bersaing dengan komoditas impor.

Menghadapi era perdagangan bebas maka usaha komoditas peternakan harus dilaksanakan secara efisien dan menghasilkan produk peternakan yang berkualitas dan berorientasi pada pasar lokal maupun global serta memiliki daya saing yang tinggi dengan memanfaatkan sumberdaya lokal secara optimal dan menggunakan teknologi tepat guna. Hal ini sebenarnya merupakan prospek yang sangat baik bagi pengembangan usaha sapi perah khususnya di DIY, sebagai daerah pengembangan sapi perah, yaitu melalui usaha peningkatan populasi, produktivitas, dan efisiensi guna memenuhi kebutuhan regional maupun nasional dan sekaligus peningkatan daya saingnya terhadap susu impor sehingga terjadi substitusi impor.

\section{Materi dan Metode}

Penelitian dilakukan di Kecamatan Cangkringan, Pakem, Tempel, dan Turi, Kabupaten Sleman DIY. Penentuan responden dilakukan secara stratified sampling dua tahap. Tahap pertama, sampel distratifikasikan berdasarkan jumlah pemilikan sapi perah, yaitu satu sampai tiga Unit Ternak (UT) dan lebih dari tiga UT. Stratifikasi ini dilakukan mengingat sebagian besar peternakan sapi perah di Indonesia adalah dengan pemilikan yang rendah seperti yang dikemukakan Ebenezer (1995) bahwa $80 \%$ peternak sapi perah berusaha dengan skala kecil yaitu dengan pemilikan kurang dari empat ekor, $17 \%$ berskala menengah dengan pemilikan berkisar antara empat sampai tujuh ekor, dan $3 \%$ adalah berskala besar dengan pemilikan lebih dari tujuh ekor. Pada penelitian ini pembagian strata dengan kategori pemilikan hanya dibagi dua yaitu satu sampai tiga UT dan lebih dari 3 UT karena di lapangan untuk mendapatkan responden dengan pemilikan lebih dari tujuh ekor dengan semua produksi dipasarkan ke IPS, sulit diperoleh. Tahap kedua, masing-masing strata tahap pertama distratifikasikan menurut skala pemilikan sapi laktasi, yaitu kurang dari $70 \%$ dan lebih besar atau sama dengan $70 \%$ dari total pemilikan. Pembagian ini berdasarkan modifikasi dari penelitian Djaja (1991) yang melaporkan bahwa agar kelangsungan usaha dan kontinyuitas produksi terjaga maka komposisi ternak pada usahatani sapi perah adalah $84,52 \%$ ternak produktif dan sisanya adalah non produktif, sedangkan menurut Sudono yang disitasi oleh Hartono (1996) menjelaskan bahwa imbangan yang ideal antara sapi kering dan sapi laktasi adalah 1:4., Dari dua tahap stratifikasi tersebut diperoleh empat strata responden, yaitu pemilikan satu sampai tiga UT dengan jumlah sapi laktasi $<70 \%$ (strata 1$)$, pemilikan satu sampai tiga UT dengan jumlah sapi laktasi $\geq$ $70 \%$ (strata 2)pemilikan $>3$ UT dengan jumlah sapi laktasi $<70 \%$ (strata 3), dan pemilikan > 3UT dengan jumlah sapi laktasi $\geq 70 \%$ (strata 4). Analisis data menggunakan Policy Analysis Matrix (PAM) (Monke dan Pearson, 1995).

\section{Hasil dan Pembahasan}

\section{Pemilikan sapi perah}

Perincian komposisi pemilikan ternak ditampilkan pada Tabel 1 yang terlihat bahwa tidak ada responden yang memelihara pejantan. Hal ini disebabkan karena perkawinan ternak menggunakan inseminasi buatan (IB) sehingga pejantan tidak diperlukan lagi. Apabila pada kelahiran diperoleh pedet jantan, mereka akan menjualnya pada saat lepas sapih.

\section{Penampilan reproduksi}

Pada pemeliharaan sapi perah, aspek reproduksi harus diperhatikan sebab untung rugi 
usaha ini sangat tergantung pada penampilan reproduksi ternak karena akan mempengaruhi produktivitas ternak. Perera (1999) menyatakan bahwa sebuah persyaratan yang penting untuk keberlanjutan suatu usaha peternakan sapi perah adalah penampilan reproduksi ternak yang efisien. Lebih lanjut dikatakan bahwa beberapa aspek reproduksi dapat menjadi penyumbang utama terjadinya penurunan keuntungan bahkan kerugian, seperti tertundanya pubertas, jarak beranak (calving interval) yang panjang, masa produksi yang pendek (karena infertil atau steril) dan tingkat mortalitas pedet yang tinggi. Tabel 2 memuat beberapa aspek reproduksi sapi perah yang optimum maupun yang aktual yang terjadi di lapangan (responden).

Dari Tabel 2 terlihat bahwa karena keterbatasan data yang diperoleh, yang disebabkan peternak tidak melakukan recording, maka beberapa indikasi reproduksi tidak dapat ditampilkan. Jarak beranak dan S/C aktual masih jauh dari kondisi optimum maupun acceptable. Jarak beranak yang panjang yaitu 14,32 bulan yang berarti masa laktasi juga panjang yaitu 12,32 bulan, lebih panjang dari masa laktasi yang ideal yaitu 10 bulan akan menyebabkan produksi per tahun berkurang. Dengan kondisi indikasi reproduksi yang belum optimal ini maka produktivitas ternak juga rendah yaitu berturut- turut strata 1, 2, 3, 4, dan DIY per UT/th adalah $1.264,64$ liter, $1.958,38$ liter, $1.354,67$ liter, 2.312,31 liter dan 1.722,50 liter. Untuk produksi per induk laktasi berturut-turut adalah 2.728,45 liter, $2.453,67$ liter, $2.773,55$ liter, $2.837,35$ liter dan 2.698,26liter.

Menurut hasil sertifikasi Balai Pembibitan Ternak dan Hijauan Makanan Ternak Baturraden ada tiga kategori sertifikasi yaitu kelas C (4.000-5.000 liter/ekor/laktasi), kelas B (5.001-6.000 liter/ekor/laktasi) dan kelas A (> 6.000 liter/ekor/laktasi). Ini berarti bahwa sapi induk yang dipelihara peternak di DIY masih jauh dari induk sapi perah yang mempunyai sertifikat.

Indikasi reproduksi yang masih memprihatinkan dan ditambah dengan proporsi sapi produktif khususnya sapi laktasi yang belum optimal ini menjadi salah satu penyumbang produktivitas yang rendah pada usaha sapi perah.

Peternak sebaiknya mengatur jumlah sapi produktif dan non produktif yang dipeliharanya agar kelangsungan usaha dapat terjaga dan produksi susu relatif konstan sepanjang tahun. Dengan memperhatikan hal itu, peternak dapat mengelola sapi perahnya untuk berproduksi secara maksimal baik kuantitas maupun kualitas. Pengaturan komposisi ini sangat penting karena perbandingan antara ternak produktif dan non

Tabel 1. Komposisi pemilikan sapi perah (Composition of dairy cattle ownership)

\begin{tabular}{|c|c|c|c|c|c|c|c|}
\hline \multirow{3}{*}{$\begin{array}{c}\text { Strata } \\
\text { (Stratum) }\end{array}$} & \multicolumn{5}{|c|}{ Jumlah (Number) } & \multicolumn{2}{|c|}{ Total } \\
\hline & \multicolumn{2}{|c|}{$\begin{array}{l}\text { Induk (Ekor) } \\
\text { (Cow (Head)) }\end{array}$} & \multirow{2}{*}{$\begin{array}{c}\text { Pejantan } \\
\text { (Ekor) } \\
\text { (Bull } \\
\text { (Head)) }\end{array}$} & \multirow{2}{*}{$\begin{array}{c}\text { Dara (Ekor) } \\
\text { (Heifer } \\
\text { (Head)) }\end{array}$} & \multirow[t]{2}{*}{$\begin{array}{l}\text { Pedet (Ekor) } \\
\text { (Calf (Head)) }\end{array}$} & \multirow{2}{*}{$\begin{array}{l}\text { Ekor } \\
\text { (Head) }\end{array}$} & \multirow[b]{2}{*}{ UT $(A U)$} \\
\hline & $\begin{array}{c}\text { Laktasi } \\
\text { (Lactation) }\end{array}$ & $\begin{array}{l}\text { Kering } \\
\text { (Dry) }\end{array}$ & & & & & \\
\hline I & 1,03 & 0,40 & - & 0,54 & 0,97 & 2,94 & 2,19 \\
\hline 2 & 1,64 & 0,09 & - & 0,16 & 1,02 & 2,91 & 1,95 \\
\hline 3 & 2,55 & 0,85 & - & 0,72 & 1,03 & 5,15 & 4,81 \\
\hline 4 & 4,54 & 0,11 & - & 0,64 & 2,14 & 7,43 & 5,23 \\
\hline DIY & 2,44 & 0,36 & - & 0,52 & 1,29 & 4,61 & 3,55 \\
\hline
\end{tabular}


Tabel 2. Beberapa indikasi reproduksi sapi perah di daerah tropis pada kondisi optimum ${ }^{\mathrm{a})}$, acceptable ${ }^{a}$ dan aktual (responden) (Reproductive indications for dairy cattle under optimum condition, suggested acceptable, and investigated performance in the tropics)

\begin{tabular}{lccc}
\hline \multicolumn{1}{c}{ Keterangan (Item) } & $\begin{array}{c}\text { Optimum } \\
\text { (Optimum) }\end{array}$ & Acceptable & $\begin{array}{c}\text { Aktual } \\
\text { (Investigated) }\end{array}$ \\
\hline $\begin{array}{l}\text { Umur pubertas (bulan) } \\
\text { (Age at puberty (month)) }\end{array}$ & $<18$ & $<24$ & tad \\
$\begin{array}{l}\text { Umur pertama beranak (bulan) } \\
\text { (Age at first calving (month)) }\end{array}$ & $<30$ & $<36$ & tad \\
$\begin{array}{l}\text { Jarak beranak (bulan) } \\
\text { (Calving interval }(\text { mont)) }\end{array}$ & $12-13$ & $13-14$ & 14,32 \\
Services per conception $(S / C)$ & $<1,6$ & $<1,8$ & 2,25 \\
\hline
\end{tabular}

a) Parera. (1999)

tad $=$ tidak ada data (there is no data).

Tabel 3. Penguasaan lahan hijauan (Occupation of forage land)

\begin{tabular}{|c|c|c|c|c|c|}
\hline \multirow{2}{*}{ Keterangan (Item) } & \multicolumn{4}{|c|}{ Strata (Stratum) } & \multirow[t]{2}{*}{ DIY } \\
\hline & 1 & 2 & 3 & 4 & \\
\hline $\begin{array}{l}\text { Khusus HMT }\left(\mathrm{m}^{2}\right) \\
\text { (Forage merely }\left(\mathrm{m}^{2}\right) \text { ) }\end{array}$ & 986,49 & 887,50 & $.037,98$ & $1.557,14$ & $1.117,28$ \\
\hline $\begin{array}{l}\text { Khusus HMT }\left(\mathrm{m}^{2} / \mathrm{UT}\right) \\
\left.\text { (Forage merely }\left(m^{2} / A U\right)\right)\end{array}$ & 450,45 & 455,13 & 215,80 & 288,36 & 352,44 \\
\hline $\begin{array}{l}\text { Tumpang sari HMT }\left(\mathrm{m}^{2}\right) \\
\left.\text { (Mix plant }\left(\mathrm{m}^{2}\right)\right)\end{array}$ & $3.029,73$ & $3.029,46$ & 6162,50 & $5.426,79$ & $4.412,12$ \\
\hline $\begin{array}{l}\text { Tumpang sari HMT } \\
\left(\mathrm{m}^{2} / \mathrm{UT}\right) \\
\left(\text { Mix plant }\left(\mathrm{m}^{2} / A U\right)\right)\end{array}$ & $1.383,44$ & $1.553,57$ & $1.281,19$ & $1.004,96$ & $1.305,79$ \\
\hline
\end{tabular}

$\mathrm{HMT}=$ hijauan makanan ternak (Forages).

produktif yang dipelihara dalam suatu usaha akan menentukan kelangsungan hidup usaha tersebut yang ditunjukkan dengan biaya produksi untuk ternak non produktif menjadi tanggungan ternak produktif, disamping untuk memperoleh kontinuitas produksi.

\section{Penguasaan lahan hijauan}

Lahan merupakan faktor yang penting dalam kelangsungan usaha sapi perah. Selain sebagai tempat usaha, lahan juga berfungsi sebagai tempat penanaman hijauan pakan ternak. Penguasaan lahan yang dimaksud adalah meliputi lahan milik sendiri maupun lahan sewaan. Informasi mengenai penguasaan lahan hijauan untuk pakan ditampilkan pada Tabel 3.

Kendatipun dari Tabel 3 terlihat bahwa makin banyak pemilikan ternak, total penguasaan lahan ada kecenderungan makin luas, namun apabila dicermati lebih lanjut, ternyata penguasaan lahan per UT makin sempit dengan penambahan pemilikan ternak. Hal ini menunjukkan bahwa di DIY ketersediaan lahan untuk HMT memang terbatas.

Menurut Soetarno (2003), satu ha lahan irigasi dapat ditanami rumput untuk memenuhi kebutuhan pakan 10-12 ekor sapi induk. Ini berarti bahwa satu ekor induk atau satu satuan 
ternak memerlukan $833,33 \quad 1.000 \mathrm{~m}^{2}$ lahan hijauan. Dengan demikian, berdasarkan Tabel 3, secara total penguasaan lahan khusus hijauan memang belum ideal, maka kesadaran peternak tentang perlunya menambah penguasaan lahan dengan bertambahnya pemilikan ternak perlu ditingkatkan.

Keuntungan usahatani sapi perah penghasil bahan baku industri pengolahan susu di DIY

Keuntungan finansial dan keunggulan kompetitif yang dicerminkan dari nilai rasio biaya privat atau privat cost ratio (PCR) ditampilkan pada Tabel 4. Nilai keuntungan privat yang diperoleh dari hasil perhitungan pada semua strata dan DIY adalah negatif kecuali strata 4. Hal ini mengindikasikan bahwa usahatani sapi perah di DIY secara finansial menghasilkan keuntungan di bawah normal $(<0)$ atau dengan kata lain merugi kecuali untuk strata 4. Kondisi ini berarti bahwa usahatani sapi perah di DIY akan dapat layak untuk dijalankan dan sekaligus dikembangkan, dengan catatan skala usaha harus $>3$ UT dengan proporsi sapi laktasi $70 \%$ atau lebih.

PCR merupakan perbandingan antara biaya faktor domestik dengan nilai tambah yang dihasilkan (yang dihitung dengan tingkat harga yang berlaku). Strata 1, 2, dan 3 serta DIY mempunyai nilai $\mathrm{PCR}>1$ yang berarti bahwa biaya input domestik tidak mampu memberikan nilai tambah yang mensisakan keuntungan bagi peternak sapi perah yang mengusahakannya karena biaya input domestik tinggi sedangkan harga privat susu cenderung rendah. Berbeda dengan strata 4 yang mempunyai nilai $P C R<1$, hal ini mengandung pengertian bahwa biaya domestik yang dikeluarkan mampu memberikan nilai tambah yang menyisakan keuntungan bagi peternak sapi perah. Keunggulan kompetitif ini tercipta karena meskipun biaya domestik cenderung tinggi dan harga privat susu cenderung rendah namun karena pemilikan ternak relatifbanyak dengan proporsi sapi laktasi yang tinggi maka biaya menjadi efisien.

Mengacu pada nilai PCR yang diperoleh pada strata 4 dari hasil perhitungan tersebut maka dapat dikatakan bahwa biaya domestik efisien secara finansial.

Pada tabel 5 ditampilkan keuntungan sosial dan nilai Domestic Resources Cost Ratio (DRCR) yang mencerminkan keunggulan komparatif.

Keuntungan sosial merupakan indikator tingkat keuntungan relatif karena dalam perhitungannya menggunakan harga sosial yaitu harga yang mencerminkan nilai kelangkaannya (social opportunity cost). Nilai sosial adalah suatu nilai yang akan terjadi pada suatu keadaan tanpa adanya distorsi atau kebijakan-kebijakan yang akan dapat berpengaruh terhadap besarnya nilai tersebut, kondisi tersebut akan terjadi pada pasar persaingan sempurna. Nilai keuntungan sosial yang diperoleh dari hasil perhitungan adalah negatif pada strata 1 dan 3 . Berdasarkan parameter keuntungan sosial tersebut maka

Tabel 4. Keuntungan finansial dan nilai PCR (Financial profits and PCR value)

\begin{tabular}{crc}
\hline Strata (Stratum) & Keuntungan finansial (Financial profits) (Rp/UT/th) & PCR \\
\hline 1 & $-919.622,00$ & 1,2509 \\
2 & $-956.498,00$ & 1,2116 \\
3 & $-1.065 .291,00$ & 1,3107 \\
4 & $532.369,00$ & 0,8963 \\
DIY & $-602.260,00$ & 1,1438 \\
\hline
\end{tabular}

$\mathrm{PCR}=$ Private Cost Ratio . 
Tabel 5. Keuntungan sosial dan nilai DRCR (Social profits and DRCR value)

\begin{tabular}{ccc}
\hline Strata (Stratum) & Keuntungan sosial (Social profits) (Rp/UT/th) & DRCR \\
\hline 1 & $-29.499,00$ & 1,0079 \\
2 & $242.794,00$ & 0,9480 \\
3 & $-280.695,00$ & 1,0796 \\
4 & $1.314 .460,00$ & 0,7525 \\
DIY & $312.028,00$ & 0,9277 \\
\hline
\end{tabular}

DRCR $=$ Domestic Resources Cost Ratio.

usahatani sapi perah di DIY masih dapat berjalan serta layak untuk diselenggarakan tanpa adanya campur tangan dari pihak luar, namun dengan catatan harus dengan proporsi sapi laktasi minimal $70 \%$ dari total pemilikan. Kondisi ini disebabkan karena dengan memiliki sapi laktasi minimal $70 \%$ dari total pemilikan maka akan menyebabkan beban biaya untuk

sapi-sapi yang tidak berproduksi dapat ditekan sehingga masih ada keuntungan.

DRCR atau rasio biaya sumberdaya domestik adalah perbandingan antara input domestik dengan nilai tambah yang dihasilkan (pada perhitungan sosial), merupakan indikator kemampuan input domestik dalam memberikan nilai tambah dalam suatu aktivitas ekonomi. Parameter tersebut dihitung dengan nilai sosial, maka nilai dari parameter tersebut memungkinkan untuk digunakan sebagai indikator keunggulan komparatif. Berdasarkan hasil perhitungan, nilai DRCR pada strata 1 dan 3 adalah $>1$ sedangkan strata 2,4 , dan DIY adalah $<1$. Dengan nilai DRCR $>1$ untuk strata 1 dan 3 memberi arti bahwa biaya domestik yang dikeluarkan pada kedua strata tersebut tidak mampu memberikan nilai tambah yang lebih besar. Kondisi ini disebabkan karena proporsi sapi laktasi rendah (strata 1 dan 3 ) sehingga biaya produksi tidak efisien. Angka DRCR $<1$ untuk strata 2, 4, dan DIY mengindikasikan bahwa nilai tambah yang dihasilkan lebih besar daripada biaya domestik yang dikeluarkan atau dengan kata lain biaya-biaya domestik efisien dalam menghasilkan nilai tambah. Dengan demikian, biaya domestik mempunyai keunggulan komparatif untuk memproduksi susu segar pada peternak sapi perah strata 2, 4, dan DIY.

\section{Analisis sensitivitas}

Analisis sensitivitas dilakukan pada beberapa variabel dalam kerangka pikir upaya peningkatan kinerja sistim dalam mencapai tingkat keuntungan yang positif dan keunggulan komparatif maupun kompetitif.

Dari analisis diperoleh hasil bahwa untuk tingkat keuntungan finansial yang positif dan sekaligus mempunyai keunggulan kompetitif adalah hanya strata 4 , sedangkan untuk keuntungan sosial yang positif dan sekaligus mempunyai keunggulan komparatif adalah strata 2,4 , dan rata-rata DIY.

\section{Keuntungan finansial dan keunggulan kompetitif.}

Harga jual susu segar. Seperti diketahui bahwa peternakan sapi perah nasional sangat menggantungkan pasar pada IPS yang jumlahnya sangat terbatas. Keadaan ini menciptakan struktur pasar yang cenderung oligopsoni, bahkan kondisi di DIY adalah monopsoni, sehingga peternak tidak mempunyai bargaining power untuk menentukan harga jual susu segar. Pada penelitian ini harga jual susu segar ditingkat koperasi rata-rata $\mathrm{Rp}$ $1.559,83 /$ liter. Meskipun telah dikenakan tarif impor sebesar $5 \%$, namun harga ini masih lebih rendah bila dibandingkan dengan harga bayangannya yaitu $\mathrm{Rp}$. 1.640,95/liter. $\mathrm{Hal}$ ini terjadi karena adanya distorsi pasar, sehingga struktur pasar cenderung monopsoni. Tingkat harga jual susu segar berkaitan erat dengan tingkat keuntungan finansial dan keunggulan kompetitif. Rata-rata usahatani sapi perah di DIY akan memperoleh keuntungan finansial yang positif sekaligus mempunyai keunggulan 
kompetitif $(\mathrm{PCR}<1)$ apabila harga susu segar di tingkat koperasi naik di atas $22,41 \%$ atau $\mathrm{Rp}$ $1.909,57$ per liter, atau harga ditingkat peternak (rata-rata DIY) diatas Rp. 1582,55/liter.

Tarif impor. Upaya peningkatan tingkat keuntungan finansial dalam lingkungan internasional yang terdistorsi dapat dilakukan melalui mekanisme pengenaan tarif terhadap bahan baku susu impor, apalagi kesepakatan global dalam WTO (World Trade Organization) juga masih memungkinkan. Seperti telah diketahui bahwa globalisasi pasar baru akan diterapkan pada tahun 2020 sehingga waktu yang tersisa ini sebenarnya dapat dimanfaatkan untuk mengkaji ulang penetapan tarif impor susu sekaligus untuk mempersiapkan industri persusuan domestik dalam menghadapi pasar global mendatang. Hasil analisis menunjukkan bahwa rata-rata usahatani sapi perah di DIY akan memperoleh keuntungan finansial yang positif dan keunggulan kompetitif ( $\mathrm{PCR}<1$ ) apabila pengenaan tarif impor susu di atas $34 \%$.

\section{Keuntungan sosial dan keunggulan komparatif.}

Nilai tukar rupiah. Usahatani sapi perah yang memproduksi susu segar sebagai pemasok bahan baku IPS mempunyai tujuan untuk substitusi impor. Dengan demikian nilai tukar sangat berpengaruh terhadap kelanjutan usahatani sapi perah. perubahan nilai tukar rupiah dalam hal ini menguat dibawah $11,05 \%$, sehingga mencapai kisaran di atas Rp 8.555,62 per US\$ untuk nilai tukar bayangan maka usahatani sapi perah akan dapat bertahan memperoleh keuntungan sosial positif sekaligus mempunyai keunggulan komparatif(DRCR<1).

Harga bahan baku susu impor. Sebagai penyedia bahan substitusi susu impor, kaitannya sebagai bahan baku IPS, usahatani sapi perah keberadaannya sangat dipengaruhi oleh harga susu impor. Makin tinggi harga susu impor maka akan makin memiliki keunggulan komparatif. Usahatani sapi perah di DIY akan dapat bertahan memperoleh keuntungan sosial yang positif sekaligus mempunyai keunggulan komparatif (DRCR $<1$ ) apabila harga susu impor dengan kualitas seperti susu domestik mencapai harga di atas Rp1.459,80 per liter atau turun dibawah $11,04 \%$.

\section{Dukungan kebijakan yang diperlukan}

Mencermati pembahasan di atas, beberapa dukungan kebijakan diperlukan untuk mendorong keberadaan usahatani sapi perah maupun industri persusuan domestik. Dukungan tersebut antara lain:

(1) Tingkat tarif impor susu.

Saat ini proteksi yang telah diberlakukan adalah tarif impor bahan baku susu sebesar $5 \%$. Namun dalam kondisi ini ternyata koefisien proteksi efektif masih $<1$, sehingga mengindikasikan bahwa usahatani sapi perah mengalami disinsentif. Untuk itu tingkat pengenaan tarif perlu dikaji ulang.

(2) Penetapan harga susu segar domestik.

Agar usahatani sapi perah layak dan memperoleh keuntungan yang sewajarnya maka diperlukan dukungan dari pemerintah untuk menetapkan harga jual susu ditingkat peternak. Bonus harga yang berkaitan dengan peningkatan kualitas susu ditetapkan secara signifikan, sehingga dampaknya terasa. Harga yang wajar dan menarik tentu akan berimbas pada tingkat kualitas susu. Upaya ini diharapkan dapat memotivasi peternak dalam meningkatkan kualitas susu.

\section{Kesimpulan dan Saran}

\section{Kesimpulan}

(1) Usahatani sapi perah penghasil bahan baku IPS di DIY yang sustainaible dan sekaligus mempunyai keunggulan kompetitif serta keunggulan komparatif adalah strata 4 , yakni dengan pemilikan $>3$ UT atau ratarata pemilikan 5,23 UT dan proporsi sapi laktasi $\geq 70 \%$.

(2) Analisis sensitivitas menunjukkan bahwa keuntungan finansial dan keunggulan kompetitif usahatani sapi perah akan tercapai apabila: (a) harga jual susu segar di tingkat koperasi naik di atas $22,41 \%$, atau (b) tingkat pengenaan tarif impor bahan baku susu naik menjadi di atas $34 \%$. 
Keuntungan sosial dan keunggulan komparatif usahatani sapi perah akan bertahan apabila: (a) nilai tukar rupiah menguat dibawah $11,05 \%$, atau (b) harga bahan baku susu impor turun dibawah $11,04 \%$.

\section{Saran}

Kebijakan pemerintah yang berkaitan dengan pengembangan sapi perah hendaknya lebih difokuskan ke aspek ekonomi bukan aspek sosial, sebab usahatani sapi perah memerlukan paket teknologi tersendiri yang membutuhkan biaya yang relatif mahal, oleh karena itu perlu dibatasi pemilikan minimal serta diperhatikan proporsi sapi laktasi.

\section{Daftar Pustaka}

Djaja, W. 1991. Perhitungan Jumlah Sapi Produktif dan Non Produktif. Buletin PPSKI Nomor 33 Th VII April Juni 1991.

Ebenezer, S. H. E. 1995. Pengaruh WTO Bidang Peternakan Terhadap Perdagangan Produk Pertanian Indonesia. Buletin Ekonomi Bappindo No 4 Th XX. Jakarta.

Hartono, B. 1996. Faktor Produksi Yang Berpengaruh Terhadap Biaya Produksi Susu Peternakan Sapi Perah di Kecamatan Karangploso, Kabupaten Malang, Jawa
Timur. Buletin Peternakan Vol. 20 (2) 1996. Fakultas Peternakan UGM Yogyakarta.

Januar. 2002. Upaya-upaya Menata Kembali Kebijakan Pertanian Di Bidang Ketahanan Pangan Dalam Wacana Otonomi Daerah. Proceeding Round Table Kebijakan Pangan Nasional Dalam Kerangka Otonomi Daerah. Magister Manajemen Agribisnis Universitas Gadjah Mada Yogyakarta.

Monke, E.A. and S. R. Pearson. 1995. The Policy Analysis Matrix for Agricultural Development. Cornell University Press. Ithaca and London.

Perera, O. 1999. Management and Reproduction. Smallholder Dairying in The Tropics. International Livestock Research Institute. Nairobi. Kenya.

Pindyck, R. S. and D. L. Rubenfield. 1998. Micro Economics. Prentice Hall International Inc. Upper Saddle River. New Jersey 07458.

Soetarno, T. 2003. Manajemen Ternak Perah. Edisi Kenangan Purna Tugas. Laboratorium Ternak Perah Fakultas Peternakan UGM. Yogyakarta.

Warr, P. G. 1992. Comparative and Protection in Indonesia. Bulletin of Indonesian Economic Studies. 28(3). The Australian National University. 